\title{
Alguns resultados sobre os critérios de convergência macroeconômica no âmbito do Mercosul
}

\author{
Luiz Carlos Ribeiro Neduziak ${ }^{1}$
}

\section{RESUMO}

Os critérios de convergência econômica apontam para a baixa confluência das variáveis econômicas - PIB (Produto Interno Bruto), taxa de câmbio e demanda internacional no âmbito do Mercado Comum do Sul. Entretanto, do ponto de vista dos caracteres não dessemelhantes, como população, sociedade e cultura, o resultado é outro. O presente ensaio busca resgatar algumas considerações sobre a temática em tela à luz dos acontecimentos recentes neste espaço regional.

Palavras-chave: MERCOSUL; Convergência Macroeconômica.

Dois tipos de estudos podem ser empreendidos quando se pretende analisar a convergência de variáveis macroeconômicas e socioculturais entre países que buscam o aprofundamento do processo de integração econômica. Por um lado, há os de caráter estritamente econômico, fundamentados na análise da convergência de resposta de variáveis econômicas selecionadas, tais como o PIB (Produto Interno Bruto) e a taxa de câmbio, diante de um choque externo - uma crise econômica, por exemplo; e, por outro, os estudos descritivos dos caracteres socioculturais dos Estados, como a cultura, a forma de governo, o colonizador, a evolução inflacionária e as fronteiras terrestres (FRANKEL e ROSE, 1997).

Entretanto, os resultados dessas duas vertentes apontam para caminhos diametralmente opostos. Enquanto o primeiro demonstra que o comportamento das variáveis macroeconômicas mercosulinas é destoante em face de um choque exógeno de demanda, aquele último assinala o contrário.

\footnotetext{
${ }^{1}$ Doutorando pelo Programa de Pós-Graduação em Economia da UFPR.

Conjuntura Global, Curitiba, Vol. 2, n.1, jan./mar., 2013, p. 16-18.
} 
Nesse sentido, ressalta-se que esses países são nações de mesmo colonizador comum, à exceção do Brasil, que foi colonizado por Portugal. A despeito dessa sutil diferença, trata-se de povos de mesma estirpe ibérica (hispano-portuguesa) e católica (DE HOLANDA, 1936), que compartilham fronteiras entre si e adotam a mesma forma de governo republicano.

A colonização que no espaço sul-americano se processou, independente da nação que a fizera, foi caracterizada por um sentido, uma linha mestra que a "ordenava" (JÚNIOR, 1942). Dessa maneira, muito embora a nação brasileira se tenha colonizado por Portugal, dissolve-se essa diferença pelo sentido da colonização.

Em sua história econômica recente, os países do Cone Sul apresentaram quadros inflacionários (crises financeiras) que beiravam a hiperinflação. A fragilidade de suas moedas foi sanada pela consecução de planos de estabilização e a construção de novos padrões monetários.

Por outro lado, tendo em vista os estudos de caráter puramente econômico, a conclusão inverte-se de todo. Neduziak (2012) constrói um modelo de simetria a choques entre Argentina, Brasil, Uruguai e Venezuela, objetivando verificar de que maneira esses países respondem a um choque de demanda externa. Segundo a teoria econômica, espera-se que quanto maior a simetria a choques entre um pool de países, mais apropriada a utilização de instituições econômicas comuns e, em última instância, o aprofundamento do processo de integração.

Enquanto que a Argentina e o Brasil exibem comportamento muito semelhante no que toca à resposta dos PIBs nacionais à variação da taxa de câmbio e demanda internacional, Uruguai e Venezuela destoam, sendo o peso do setor externo para este país muito maior do que para os demais. Isso quer dizer que os países que compõem o MERCOSUL possuem dessemelhanças macroeconômicas não desprezíveis, apesar das semelhanças socioculturais.

Recentemente, autoridades estadunidenses e europeias vêm sinalizando um aprofundamento do comércio entre as duas maiores economias do mundo, por meio da criação de uma zona de livre comércio intercontinental. Há mais de uma década, o 
mesmo "tipo" de acordo vem sendo negociado entre o velho continente e o MERCOSUL, não obstante engessadas as negociações.

Apesar de o MERCOSUL e a União Europeia (UE) terem retomado negociações para a abertura de mercados, o flanco exposto das negociações permanece ainda na questão da agroindústria, sobretudo a do mercado de carne argentino, do lado de cá, e da política agrícola, do lado de lá. Nesse sentido, a Argentina mostra-se reticente quanto à liberação do comércio interblocos, bem como com a situação política no país vizinho (Paraguai), que estará suspenso do bloco até as próximas eleições em abril deste ano.

\section{Referências bibliográficas}

DE HOLANDA, Sérgio Buarque. Raízes do Brasil. $26^{\circ}$ edição. São Paulo : Cia das Letras, 1995.

FRANKEL, Jeffrey; ROSE, Andrew. The endogenity of the optimum currency area criterium. NBER Working Paper, n. 5700. Cambridge, 1996. Disponível: <http:// http://www.nber.org/papers/w5700.pdf?new_window=1>. Acesso em: 5/5/2011.

JÚNIOR, Caio Prado. Formação do Brasil Contemporâneo. 23edição. São Paulo: Brasiliense, 2004.

NEDUZIAK, Luiz Carlos Ribeiro. Uma visão política acerca do processo de integração econômica no MERCOSUL. Dissertação - Programa de Pós-Graduação em Economia da Universidade Federal do Rio Grande do Sul, Rio Grande do Sul, 2012. 